\title{
Analysis of The Effect of Work Motivation on Performance of Employees in Media Café, Kedoya West Jakarta
}

\author{
Fernando Adam Hainim¹, Candra Hidayat ${ }^{2}$ \\ Sekolah Tinggi Pariwisata Trisakti \\ fernandoadambainim@gmail.com ${ }^{1}$ \\ candra.bidayat@stptrisakti.ac.id²
}

\begin{abstract}
Managing Human Resources is an essential role of a manager. By having highly motivated employees, an organization can achieve its vision by fulfilling its mission using its set values. Therefore, employees' motivation is an important factor in their performance. This research was conducted at Media Café, by using work motivation (need of achievement, need of affiliation, and need of power) as the independent variable and employees' performance as the dependent variable. The purpose of this research is to determine the influence of the work motivation variables stated above on the performance of Media Café's employees. This research is descriptive and causal. Data were analyzed by using descriptive analysis, multiple linear regression analysis, simultaneous hypothesis test (F test), the partial hypothesis testing ( $\mathrm{t}$-test), and the coefficient of determination. Sampling technique is used Proportionate Stratified Random Sampling. Based on questionnaire with 100 respondents, employees' work motivation and performance were very high. In the hypothesis testing results, it can be concluded that the work motivation variables consisting of Need for Achievement (X1) and Need for Power (X3) individually had significant influence on performance with $11.2 \%$ and $10.73 \%$ respectively while Need for Affiliation (X2) had no significant influence on employee performance with $0.06 \%$. Simultaneously, Need for Achievement (X1), Need for Affiliation (X2) and Need for Power (X3) had significant effect on employee performance (Y). In the test results the adjusted coefficient of determination (adjusted R2) obtained a value of 0.196 , this means that the influence of work motivation on employee performance was $19.6 \%$, while the remaining $80.4 \%$ was influenced by other factors not examined in this study.
\end{abstract}

Keywords: Managing Human Resources, Employees’ Motivation, Work Performance 


\section{A. Introduction}

Human resources (HR) have an important role as a potential driver of all company activities. Every company must be able to maintain and improve the quality of its HR performance (Larasati and Gilang, 2014). Performance appraisal is used to stipulate the extent to its associate employee performs his/her work effectively (Ranga and Kamboj, 2018). This applies to all companies engaged in all fields of industry, especially companies engaged in the service industry (Suparyadi, 2015). Based on the trend of this service business, whether restaurants or other types of services, companies must realize that the role of HR is increasingly important, the quality of human resources determines the lives of companies and equipment and technology acts as a supporter (Dessler 2010; Suparyadi, 2015).

One of the Media Group's catering companies, PT Indocater, is a food and beverage provider for its employees at the Metro TV headquarters and studio in Kedoya, West Jakarta. The name of PT Indocater's business unit is Media Café (PT Indocater, 2012).

One way for Media Café to measure the performance of its HR is through a customer satisfaction survey conducted every three months. In this three-month period, customer satisfaction was measured through three variables, namely service / service, food quality and variety of food menus. The survey results can be seen in the table below:

Table 1. Media Café Customer Satisfaction Data Quarter III and IV

\begin{tabular}{|l|c|c|c|c|}
\hline \multirow{2}{*}{ QUALITY OBJECTIVES } & \multicolumn{2}{|c|}{ June-September 2015 } & \multicolumn{2}{c|}{ October-December 2015 } \\
\cline { 2 - 5 } & Target & Realization & Target & Realization \\
\hline Service & $50 \%$ & $52,32 \%$ & $50 \%$ & $51,07 \%$ \\
Food Quality & $50 \%$ & $50 \%$ & $50 \%$ & $53,94 \%$ \\
Food Menu Variation & $50 \%$ & $50,58 \%$ & $50 \%$ & $52,86 \%$ \\
\hline
\end{tabular}

Source: Media Café Unit Manager Data (2015)

Based on Table 1, it was found that there was a decrease in service quality from Quarter III which was $52.32 \%$ to $51.07 \%$ in Quarter IV. Although this figure is still above the target of $50 \%$, it is clear that the decline in the quality of service must be taken seriously by management. This decrease in service quality shows a decrease in the service of Media Café.

Food quality has increased from $50 \%$ in the third quarter to $53.94 \%$ in the fourth quarter. This is a positive achievement that shows an increase in the performance of Media Cafe kitchen employees but the level of improvement is still inadequate.

Meanwhile, food menu variations also gained an increase in the third quarter, from $50.58 \%$ to $52.86 \%$ in the fourth quarter. This shows an increase in the performance of Media Café employees on the menu variation side but the increase can still be higher. 
Based on Media Cafe Customer Satisfaction Data Quarter III and IV, it can be seen that there is a problem with the performance of Media Café employees and therefore, in the subsequent performance appraisal, more attention is given to why the performance of the Media Café employees decreases and / or does not increase as high as desired.

From the data taken from Table 1 above and the background of the research that has been expressed, the question arises as to how to improve the performance of Media Café employees so as to be able to provide good service, maintain it, and if possible, improve the quality of food and serve a more diverse variety of food menus. Of course the answers to these questions are diverse and can be seen from various factors but the factors discussed by the authors in this study are employee motivation factors and their relationship to employee performance.

The following are the objectives of this study:

a. To analyze the work motivation of Media Café employees.

b. To analyze the performance of Media Café employees.

c. To analyze the impact of work motivation on the performance of Media Café employees.

Therefore, this study is titled "Analysis of the Effect of Work Motivation on Employee Performance of Media Café, Kedoya, West Jakarta."

\section{B. Literature Review}

One way that can be done by Media Cafe in improving the quality of performance is to pay attention in the form of work motivation to employees. In addition, the most important thing that must be done by the company, is how employees can enjoy their work so that employees can do the work without any pressure (Larasati and Gilang 2014). Based on the results of research by Suwardi and Utomo (2011), Hamid (2012), Murti and Srimulyani (2013), and Permanasari (2013) which was cited by Larasati and Gilang (2014), it was found that work motivation significantly had a positive effect on employee performance. Another study conducted by Salleh et al. (2011) and research from Susan et al. (2012) also stated that work motivation has a positive and significant influence on employee performance.

According to the concept of Wirawan (2009), employee performance can be measured through employee work results, employee work behavior and the personal nature of employees that are related to work. The three things mentioned above play a major role in employee performance.

Based on the aforementioned reference, the next diagram illustrate the frame of reference of this study: 
Diagram 1. Frame of Reference

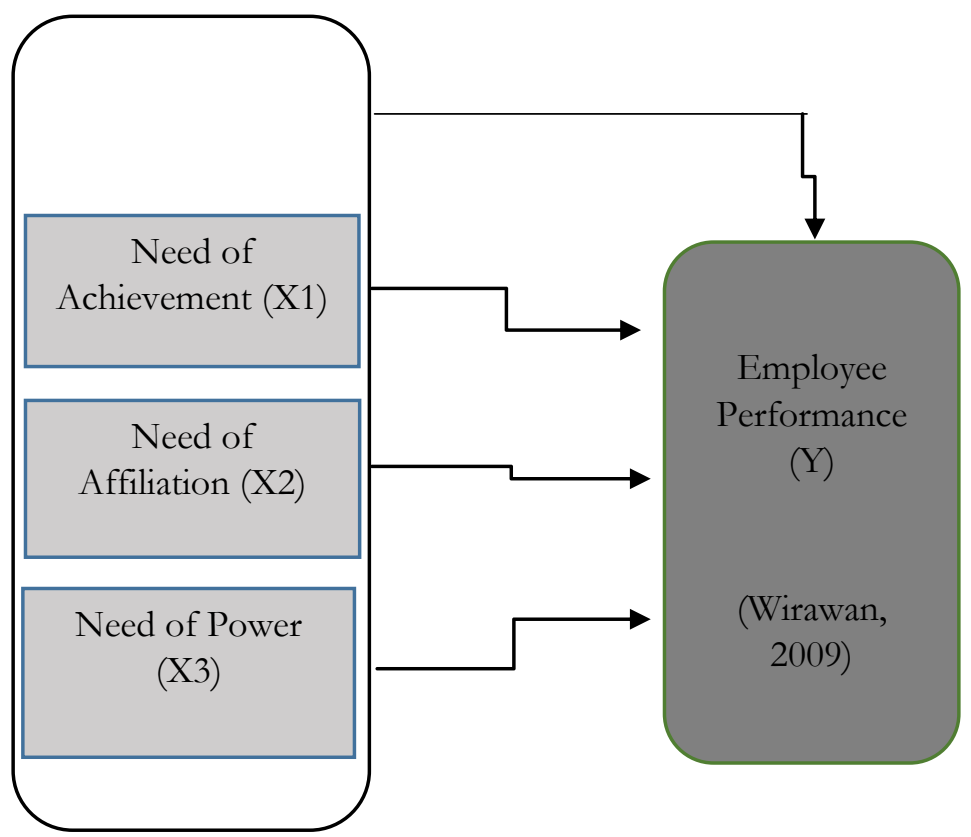

\section{Research Methods}

The type of research used on this occasion is descriptive and causal. Therefore, in this descriptive study, it will be described or told how is the work motivation of employees and the performance of employees at Media Café, Kedoya, West Jakarta. This study also uses the causal method because one of the three problem formulations in this study asks a causal relationship between two variables. In this causal research, it will examine how is the influence of employee motivation on employee performance at Media Café, Kedoya, West Jakarta. This research is conducted at Media Café, Jl. Pilar Mas Raya, Kav. A - D, Kedoya Selatan, Kebun Jeruk, West Jakarta with a research period from April 2016 to August 2016.

The operational variables used in this study are as follows:

1. Independent Variables

Independent variable used in this study is the Work Motivation variable $(\mathrm{X})$ based on McClelland's theory as quoted by Mangkunegara (2007).

a. Need of Achievement (X1):

1. Innovation

2. Creativity

3. Feedback

4. Challenges

5. Work Ethic

b. Need of Affiliation (X2)

1. Socialization

2. Interpersonal Relations

3. Friendship 
c. Need of Power (X3)

1. Competition

2. Authority

3. Position

2. Dependent Variables

The dependent variable used in this study is the Employee Performance variable (Y) based on the concept of Wirawan (2009):

a. Work result

b. Work Behavior

c. Personal traits that have to do with work.

To clarify the variables and measurements used, the following table contains variables, sub-variables, indicators, and the scale used in this research:

Table 2. Variables, Sub-variables, Indicators, and Research Scale

\begin{tabular}{|c|c|c|c|c|}
\hline No. & Variables & Sub-variables & Indicators & Scale \\
\hline \multirow[t]{3}{*}{1.} & $\begin{array}{l}\text { Work Motivation } \\
\text { (X) } \\
\text { Need of } \\
\text { Achievement } \\
\text { (X1) }\end{array}$ & & $\begin{array}{ll}\text { 1. } & \text { Innovation } \\
\text { 2. } & \text { Creativity } \\
\text { 3. } & \text { Feedback } \\
\text { 4. } & \text { Challenge } \\
\text { 5. } & \text { Working Ethics }\end{array}$ & Likert \\
\hline & $\begin{array}{l}\text { Need of } \\
\text { Affiliation (X2) }\end{array}$ & & $\begin{array}{ll}\text { 1. } & \text { Socialization } \\
\text { 2. } & \text { Interpersonal } \\
& \text { Relations } \\
\text { 3. } & \text { Friendship }\end{array}$ & Likert \\
\hline & $\begin{array}{l}\text { Need of Power } \\
\text { (X3) }\end{array}$ & & $\begin{array}{ll}\text { 1. } & \text { Competition } \\
\text { 2. Authority } \\
\text { 3. } & \text { Position } \\
\end{array}$ & Likert \\
\hline 2. & $\begin{array}{l}\text { Employee } \\
\text { Performance }(\mathrm{Y})\end{array}$ & $\begin{array}{l}\text { 1. Work Result } \\
\text { 2. Work Behavior } \\
\text { 3. Personal Traits that } \\
\text { are related to Work }\end{array}$ & $\begin{array}{ll}\text { 1. } & \text { Quality } \\
\text { 2. } & \text { Quantity } \\
\text { 3. } & \text { Accuracy } \\
\text { 4. } & \text { Speed } \\
\text { 1. } & \text { Discipline } \\
\text { 2. } & \text { Leadership } \\
\text { 3. } & \text { Thoroughness } \\
\text { 4. } & \text { Cooperation } \\
\text { 1. } & \text { Initiative } \\
\text { 2. } & \text { Honesty } \\
\text { 3. } & \text { Skill } \\
\text { 4. } & \text { Working Ethic }\end{array}$ & Likert \\
\hline
\end{tabular}

Source: Processed based on Larasati and Gilang (2014)

Based on the independent variables (X1, X2 and X3) and dependent variables $(\mathrm{Y})$ above, a questionnaire is created to find out what the achievement 
needs, affiliate needs, power requirements and performance of Media Café employees are.

To measure respondent's approval of the object of concern, this study uses a questionnaire that has scaled and labeled questions. This questionnaire uses a Likert Scale. According to Sugiarto, et al. (2015), the Likert scale uses five assessment numbers, namely: (1) strongly disagree, (2) disagree, (3) uncertain or neutral, (4) agree, (5) strongly agree.

The population in this study are all employees of Media Café, Kedoya, West Jakarta, as many as 133 employees categorized by position or position namely Unit Manager position, Assistant Unit Manager, Coordinator, Executive Chef, Sous Chef, Supervisor, Senior Staff and Staff. Below is the number of employees at Media Café, Kedoya, West Jakarta based on position or position:

Table 3. The Number of Employees at Media Café, Kedoya, West Jakarta

\begin{tabular}{|c|l|c|}
\hline No. & \multicolumn{1}{|c|}{ Position } & $\begin{array}{c}\text { Number of Employees } \\
\text { (person) }\end{array}$ \\
\hline 1. & Unit Manager & 1 \\
\hline 2. & Assistant Unit Manager & 1 \\
\hline 3. & Coordinator & 2 \\
\hline 4. & Executive Chef & 1 \\
\hline 5. & Sous Chef & 13 \\
\hline 6. & Supervisor & 55 \\
\hline 7. & Senior Staff & 61 \\
\hline 8. & Staff & 133 \\
\hline & Total & \\
\hline
\end{tabular}

Source: Processed according to Media Café Unit Manager (2016)

This study utilizes samples from the population using the Slovin formula (Umar 2008).

$$
\begin{gathered}
n=\frac{N}{1+N e^{2}} \\
n=\frac{N}{1+N e^{2}}=\frac{133}{1+\left(133 \times(0.05)^{2}\right)}=99.81
\end{gathered}
$$

whereas:

$n$ : number of samples

$N$ : total population

$e$ : error tolerance

Based on the sample calculation above, the number of samples to be used in this study is 100 respondents from a total population of 133 employees based on Slovin's formula.

As for the proportion of sampling, generally there are 2 types of sample collection techniques, namely: probability sampling and non-probability sampling as stated by Parasuraman, 1991 which is quoted by Tehubijuluw and Sugiarto (2014). 
Due to the fact that the population has a different distribution in the business unit, the sampling technique used is the proportionate stratified random sampling technique which is one of the probabilistic sampling techniques, namely the technique used when the population has a non-homogeneous member and proportional strata (Sugiyono, 2011) The following is the formula for the proportionate stratified random sampling from Sedarmayanti and Hidayat (2011):

$n_{i}=\frac{N i}{N} \times n \ldots \ldots \ldots \ldots \ldots$

whereas:

$n_{i} \quad$ : Number of samples according to strata

$n \quad$ : Total number of samples

$N i \quad$ : Total population according to strata

$N \quad$ : Total population

The following is the proportion of the number of samples in each position or position in Media Café, Kedoya, West Jakarta, which is sought using the formula proportionate stratified random sampling above:

Table 4. Proportion of Number of Samples in Each Position

\begin{tabular}{|c|l|c|c|c|}
\hline No. & \multicolumn{1}{|c|}{ Position } & $\begin{array}{c}\text { Number } \\
\text { of person }\end{array}$ & Sample & $\begin{array}{c}\text { Number } \\
\text { of person }\end{array}$ \\
\hline 1. & Unit Manager & 1 & $1 / 133 \mathrm{X} 100$ & 1 \\
\hline 2. & Assistant Unit Manager & 1 & $1 / 133 \mathrm{X} 100$ & 1 \\
\hline 3. & Coordinator & 2 & $2 / 133 \mathrm{X} 100$ & 1 \\
\hline 4. & Executive Chef & 1 & $1 / 133 \mathrm{X} 100$ & 1 \\
\hline 5. & Sous Chef & 1 & $1 / 133 \mathrm{X} 100$ & 1 \\
\hline 6. & Supervisor & 13 & $13 / 133 \mathrm{X} 100$ & 9 \\
\hline 7. & Senior Staff & 55 & $55 / 133 \mathrm{X} 100$ & 41 \\
\hline 8. & Staff & 61 & $61 / 133 \mathrm{X} 100$ & 45 \\
\hline & Total & 133 & & 100 \\
\hline
\end{tabular}

Source: Processed (2016)

Based on the calculation of the proportion of the number of samples in each position above, the number of respondents based on the formula of the proportionate stratified random sampling in this study is 100 respondents.

Sugiyono (2011) states that descriptive statistics are statistics used to analyze data by describing or describing collected data as they are without intending to make conclusions that apply to the general or generalizations. Descriptive analysis is used to analyze or describe employee work motivation and employee performance at Media Café, Kedoya, West Jakarta. 


\section{Results and Discussions}

\section{Description of Research Results}

To make a descriptive analysis, the author uses information from the results of the questionnaire using the Likert Scale. According to Sugiarto et al. (2015), the Likert Scale is basically an applied scale of the interval scale. So from the specified interval that $0 \%-19.99 \%=$ strongly disagree, $20 \%$ $39.99 \%=$ disagree, $40 \%-59.99 \%=$ neutral, $60 \%-79.99 \%=$ agree, and 80 $\%-100 \%$ strongly agree.

a. Descriptive Analysis of Respondents' Responses Regarding Work Motivation (X1, X2, X3)

Work motivation in this study is made as an independent variable consisting of three main variables with a total of eleven indicators.

1. Descriptive Analysis of the Need of Achievement (X1)

Table 5. Respondents' Response regarding Need of Achievement (X1)

\begin{tabular}{|c|l|r|r|r|r|r|r|r|r|}
\hline X1 & Question & 5 & 4 & 3 & 2 & 1 & Total & $\begin{array}{l}\text { Total } \\
\text { Score }\end{array}$ & $\begin{array}{l}\text { Ideal } \\
\text { Score }\end{array}$ \\
\hline 1. & Always innovating & 71 & 29 & 0 & 0 & 0 & 100 & 471 & 500 \\
& Having a high level of & & & & & & 100 & & \\
2. & creativity & 76 & 1 & 0 & 0 & & 422 & 500 \\
3. & Always expecting feedback & 26 & 72 & 2 & 0 & 0 & 100 & 424 & 500 \\
& Always ready in facing & & & & & & 100 & & \\
4. & challenges & 71 & 1 & 0 & 0 & & 427 & 500 \\
5. & Having a high work ethics & 32 & 66 & 2 & 0 & 0 & 100 & 430 & 500 \\
\hline
\end{tabular}

Source: Processed Data (2016)

Based on the calculation in the table, it shows that the value obtained is 2.174 or $86.96 \%$. Thus the Need for Achievement is in a very high category which shows that employees at Media Cafe have very high motivation in achieving high achievements.

2. Descriptive Analysis of the Need of Affiliation (X2)

Table 6. Respondents' Response regarding Need of Affiliation (X2)

\begin{tabular}{|c|c|c|c|c|c|c|c|c|c|}
\hline $\mathrm{X} 2$ & Question & 5 & 4 & 3 & 2 & 1 & Total & $\begin{array}{l}\text { Total } \\
\text { Score }\end{array}$ & $\begin{array}{l}\text { Ideal } \\
\text { Score }\end{array}$ \\
\hline 1 & Relationship is well established & 32 & 66 & 2 & 0 & 0 & 100 & 430 & 500 \\
\hline 2 & Have a good relationship with colleagues & 26 & 74 & 0 & 0 & 0 & 100 & 426 & 500 \\
\hline 3 & Friendship is well established & 36 & 64 & 0 & 0 & 0 & 100 & 436 & 500 \\
\hline & \multirow{2}{*}{\multicolumn{7}{|c|}{$\begin{array}{l}\text { Total Score } \\
\text { Percentage }\end{array}$}} & 1292 & 1500 \\
\hline & & & & & & & & $86.13 \%$ & \\
\hline
\end{tabular}

Source: Processed Data (2016) 
From the calculation in the table, it shows the value that is obtained which is 1.292 or $86.13 \%$. Thus the Need for Affiliation is in a very high category which shows that employees at Media Cafe have very high motivation to be able to interact or have a good relationship with other people.

\section{Descriptive Analysis of Need of Power (X3)}

Table 7. Respondents' Response regarding Need of Power (X3)

\begin{tabular}{|c|c|c|c|c|c|c|c|c|c|}
\hline $\begin{array}{l}X \\
3\end{array}$ & Question & 5 & 4 & 3 & 2 & 1 & Total & $\begin{array}{l}\text { Total } \\
\text { Score }\end{array}$ & $\begin{array}{l}\text { Ideal } \\
\text { Scor } \\
\mathrm{e}\end{array}$ \\
\hline 1 & Ready to face competition & 21 & 76 & 3 & 0 & 0 & 100 & 418 & 500 \\
\hline 2 & $\begin{array}{l}\text { Authority in accordance to } \\
\text { position }\end{array}$ & 23 & 75 & 2 & 0 & 0 & 100 & 421 & 500 \\
\hline 3 & Yearning for higher position & 31 & 66 & 0 & 3 & 0 & 100 & 425 & 500 \\
\hline & \multirow{2}{*}{\multicolumn{7}{|c|}{ Total Score }} & 1264 & 1500 \\
\hline & & & & & & & & $\begin{array}{r}84.27 \\
\%\end{array}$ & \\
\hline
\end{tabular}

Source: Processed Data (2016)

Based on the calculation in the table which shows the value obtained is 1.264 or $84.27 \%$. Thus, Need for Power is in a very high category which shows that employees at Media Cafe have very high motivation in achieving a power or having an influence on others.

b. Descriptive Analysis of Respondents' Responses Regarding Employee Performance $(\mathrm{Y})$

Performance is basically a result done by employees in contributing to the company. In this study the employee performance variable is used as the dependent variable which consists of three sub-variables with twelve indicators.

The first sub variable is the result of work with the indicators used are quality, quantity, accuracy, and speed. The second sub variable is work behavior with the indicators are discipline, leadership, accuracy, and cooperation. The third sub variable is a personal trait that has to do with work with indicators consisting of initiative, honesty, ability, and morale.

Table 8. Respondents' Response regarding Employee Performance (Y)

\begin{tabular}{|r|l|r|r|r|r|r|r|r|r|}
\hline $\mathbf{Y}$ & Question & $\mathbf{5}$ & $\mathbf{4}$ & $\mathbf{3}$ & $\mathbf{2}$ & $\mathbf{1}$ & Total & $\begin{array}{r}\text { Total } \\
\text { Score }\end{array}$ & $\begin{array}{c}\text { Ideal } \\
\text { Score }\end{array}$ \\
\hline 1 & Work quality is in accordance company standards & 27 & 72 & 1 & 0 & 0 & 100 & 426 & 500 \\
2 & Meeting assigned targets & 28 & 69 & 3 & 0 & 0 & 100 & 425 & 500 \\
3 & Always disciplined in finishing work & 24 & 74 & 2 & 0 & 0 & 100 & 422 & 500
\end{tabular}




\begin{tabular}{|r|l|r|r|r|r|r|r|r|r|}
\hline $\mathbf{Y}$ & $\mathbf{5}$ & $\mathbf{4}$ & $\mathbf{3}$ & $\mathbf{2}$ & $\mathbf{1}$ & Total & $\begin{array}{r}\text { Total } \\
\text { Score }\end{array}$ & $\begin{array}{c}\text { Ideal } \\
\text { Score }\end{array}$ \\
\hline 4 & Finishing work quickly & 26 & 73 & 1 & 0 & 0 & 100 & 425 & 500 \\
5 & On time mandatory attendance & 22 & 75 & 3 & 0 & 0 & 100 & 419 & 500 \\
6 & Able to lead colleagues & 24 & 73 & 3 & 0 & 0 & 100 & 421 & 500 \\
7 & Does not make mistake when finishing work & 26 & 72 & 1 & 1 & 0 & 100 & 423 & 500 \\
8 & Prefer to work together with colleagues & 31 & 67 & 2 & 0 & 0 & 100 & 429 & 500 \\
9 & Have the initiative in proposing brilliant ideas & 24 & 73 & 3 & 0 & 0 & 100 & 421 & 500 \\
10 & Honest in finishing all the work given & 28 & 71 & 1 & 0 & 0 & 100 & 427 & 500 \\
11 & Have a good ability in finishing work & 19 & 78 & 3 & 0 & 0 & 100 & 416 & 500 \\
12 & Have a high work ethic & 26 & 73 & 1 & 0 & 0 & 100 & 425 & 500 \\
\hline
\end{tabular}

Data: Processed (2016)

From the calculation in the table it can be seen that the value obtained is 5079 or $84.65 \%$. Thus the Employee Performance is in a very high category which shows that employees at Media Cafe are able to produce very high performance.

\section{Multiple Linear Regression Analysis}

The results of this regression analysis has obtained a constant of 36,674 and the achievement coefficient (X1) of 0,360 , affiliation of 0,028 while power was 0.514 so that the regression model was obtained:

$$
\mathrm{Y}=36,674+0,360 \mathrm{X} 1+0,028 \mathrm{X} 2+0,514 \mathrm{X} 3 \ldots .
$$

Note:

1. The constant value of 36,674 states that if achievement (X1), affiliation (X2) and power (X3) do not change or equal to zero, then the company performance obtained is 36,674

2. Regression coefficient of achievement is 0.360 , meaning that if achievement rises by 1 percent and other independent variables remain or zero, then performance will increase by 0.360 percent.

3. The regression coefficient of affiliation is 0.028 , meaning that if the affiliation rises by 1 percent and the other independent variables remain or zero, then the performance will increase by 0.028 percent.

4. Regression coefficient of power is 0.514 , meaning that if the power rises by 1 percent and the other independent variables remain or zero, then the performance will increase by 0.514 percent.

\section{Partial Hypothesis Testing (T Test)}

Partial hypothesis testing ( $t$ test) is used to determine the effect of independent variables consisting of Needs of Achievement, Affiliation and 
Power on Employee Performance in a partial manner. In this study the number of samples (n) used is 100 people with a significance level of $0.005(5 \%)$, and the degree of freedom (df) is $\mathrm{n}-2=100-2=98$, so that the value of $\mathrm{t}$ table was 1,984. The following is the result of partial hypothesis testing ( $t$ test).

Table 9. T Test Results

\begin{tabular}{|l|c|c|}
\hline \multicolumn{1}{|c|}{ Research Variable } & T Count & Sig. \\
\hline Need of Achievement (X1) & 3,529 & 0,001 \\
Need of Affiliation (X2) & 0,176 & 0,861 \\
Need of Power (X3) & 3,405 & 0,001 \\
\hline
\end{tabular}

Source: Data processed (2016)

Testing this hypothesis is done by comparing the value of the tcount with ttable through the significance value $\mathrm{t}$ (sig.), therefore:

1. From the results of the above calculations, tcount $>\mathrm{t}$ table $(3,529>1,984)$ then Ho1 is rejected, Ha1 is accepted with a significance level of 0.001 . Thus it can be concluded that achievement has an effect and is significant on performance.

2. From the results of the above calculation, $t$ count $>t$ table $(0.176>1.984)$ then $\mathrm{Ho} 2$ is accepted, $\mathrm{Ha} 2$ is rejected with a significance level of 0.861 . Thus it can be concluded that affiliation has no effect on performance.

3. From the results of the above calculations, tcount $>\mathrm{t}$ table $(3.405>1.984)$, then $\mathrm{Ho} 3$ is rejected, Ha3 is accepted with a significance level of 0.001 . Thus it can be concluded that power has an effect and is significant on performance.

\section{Analysis of Partial Influence}

Analysis of partial influence is used to determine how closely the influence of each independent variable on the dependent variable. In this study partial influence analysis was used to find out how much influence the Need of Achievement variable (X1), Need of Affiliation variable (X2) and Need of Power (X3) partially on Employee Performance variable (Y). The following are the results of a partial influence analysis.

Table 10. Results of Analysis of Partial Influence

\begin{tabular}{|c|c|c|c|c|}
\hline $\begin{array}{c}\text { Varia } \\
\text { ble }\end{array}$ & $\begin{array}{c}\text { Standardized } \\
\text { Coefficient Beta }\end{array}$ & $\begin{array}{c}\text { Correlation Zero } \\
\text { Order }\end{array}$ & $\begin{array}{c}\text { Partial } \\
\text { Influence }\end{array}$ & $\begin{array}{c}\text { Partial Influence } \\
(\%)\end{array}$ \\
\hline X1 & 0.32 & 0.35 & 0.1120 & 11.20 \\
X2 & 0.016 & 0.039 & 0.0006 & 0.06 \\
X3 & 0.311 & 0.345 & 0.1073 & 10.73 \\
\hline & & 0.2199 & 21.99 \\
\hline
\end{tabular}

Source: Processed Data (2016) 
Partial influence is obtained by multiplying the value of the standardized beta coefficients with the zero-order correlation value. Based on Table 4.17, the results of the analysis of partial influences indicate that the magnitude of the effect of Need of Achievement (X1) on Employee Performance (Y) is partially equal to $11.20 \%$, the amount of influence of Need of Affiliation (X2) on Employee Performance $(\mathrm{Y})$ is $0.06 \%$, and the magnitude of the influence of Need of Power (X3) on Employee Performance (Y) is 10.73\%. So the total overall effect of Need of Achievement (X1), Need of Affiliation (X2) and Need of Power (X3) on Employee Performance (Y) together is 21.99\% (22\%). The total results of the overall influence of all independent variables (X1, X2, and $\mathrm{X} 3$ ) will look the same as the value of the coefficient of determination.

Because the discovery of $\mathrm{Ha} 2$ is rejected, which means that Affiliation has no effect on Performance is not in accordance with the research hypothesis, the researcher feels the need to examine this more. The researcher conducted a further interview with Media Café Unit Manager about why Affiliation had no effect on the performance of Media Café employees. Due to the limited time of the Media Café Unit Manager, the interview was represented by the Corporate Chef of PT Indocater in charge of developing new menus, training employees, and providing employee ratings in many PT Indocater business units including the Media Café business unit.

The author, based on the above discussions about the insignificance of Affiliation to the performance of employees at Media Café, draws conclusions as follows:

1. At Media Café, Affiliation has no effect on employee performance because all employees are required to act professionally in carrying out their work and it is not influential whether they have a good relationship with other employees or not.

2. At Media Café, Affiliation is needed to be able to achieve higher achievements and positions. Therefore Achievement and Power are more influential than affiliation on employee performance.

\section{Simultaneous Hypothesis Testing (F Test)}

The simultaneous hypothesis testing (F Test) in this study is used to test the magnitude of the influence of independent variables that consist of Need of Achievement (X1), Need of Affiliation (X2) and Need of Power (X3) simultaneously or jointly to influence Employee Performance (Y). The following are the results of the simultaneous hypothesis testing (F test).

Table 11. F Test Results

\begin{tabular}{|c|c|}
\hline F & Sig. \\
\hline 9.041 & $.000^{\mathrm{b}}$ \\
\hline
\end{tabular}

Source: Processed Data (2016) 
Table 11 shows the results of the Fcount test that have obtained a value of 9.041> Ftable (3.09) with a significance value of 0,000. This means, the Motivation (Achievement, Affiliation and Power) variables jointly influence Performance.

Point percentage distribution $\mathrm{F}$ for probability $=0.05$. Proven Fcount $>$ Ftable $(9,041>3,09)$ with a significance value (sig.) 0,000 below $0.05(5 \%)$, then Ho4 is rejected and Ha4 is accepted. Based on the regression model it can be said that Achievement, Affiliation, and Power jointly influence Performance.

\section{Coefficient of Determination}

The coefficient of determination is used to see how much the contribution of independent variables that consist of Need for Achievement (X1), Need for Affiliation (X2) and Need for Power (X3) on Employee Performance $(\mathrm{Y})$ as a whole. To adjust inflation in $\mathrm{R}^{2}$ because of data overfitting, this study uses the calculation of adjusted $\mathrm{R}^{2}$ or the adjusted multiple determination coefficient. Besides that, the increase in the number of independent variables in the model will automatically increase $\mathrm{R}^{2}$ because SSE Regression starts to approach SSE around the average. The following is the calculation of the adjusted coefficient of determination:

Table 12. Coefficient of Determination

\begin{tabular}{|c|r|r|r|r|}
\hline Model & R & R Square & $\begin{array}{c}\text { Adjusted R } \\
\text { Square }\end{array}$ & $\begin{array}{c}\text { Std. Error of } \\
\text { the Estimate }\end{array}$ \\
\hline 1 & $.469^{\mathrm{a}}$ & .220 & .196 & 2.613 \\
\hline
\end{tabular}

Source: Processed Data (2016)

Based on Table 12, it can be seen that the $\mathrm{R}$ value (multiple correlation value) produced is equal to 0.469 and the value of $R$ square $\left(R^{2}\right)$ or the coefficient of determination is 0.220 . To adjust inflation in $\mathrm{R}^{2}$ because of data overfitting, the calculation of adjusted $\mathbf{R}^{2}$ or the adjusted multiple determination coefficient is used. Based on the test of the adjusted multiple determination coefficient (adjusted $\mathrm{R}^{2}$ ), the coefficient of determination obtained through adjusted $\mathrm{R}$ square is 0.196 or $19.6 \%$. The figure is used to see the contribution of the influence of the Motivation variable (Need of Achievement, Need of Affiliation, and Need of Power) on the Performance variable that is equal to $19.6 \%$, while the remaining $80.4 \%$ is influenced or explained by other variables outside of the variables tested in this study.

\section{E. Conclusion and Recommendation}

Based on the things mentioned in the previous chapters, the writer can draw conclusions from this study. The conclusions are: 
1. The independent variable of this study, namely Employee Motivation, which consists of the Need of Achievement (X1) and the Need of Power (X3), has a positive and significant effect partially on the dependent variable of this study namely Employee Performance (Y) at Media Café, Kedoya, West Jakarta. The Need of Achievement Variable (X1) has the highest partial effect $(11.20 \%)$ and the Need of Power variable (X3) has the highest second partial effect $(10.73 \%)$. This means that the more fulfilled the employee's needs of achievement and power, the higher the performance of the Media Café employees.

2. Independent variable Need for Affiliation (X2), partially has no influence on the dependent variable Employee Performance (Y) with the level of influence of $0.06 \%$. This means that the high or low motivation of employees for relationships or affiliations partially does not affect the performance of Media Café employees.

3. The independent variable of this study, namely Employee Motivation, which consists of the Need of Achievement (X1), the Need of Affiliation (X2) and the Need of Power (X3), has a positive and significant effect simultaneously on the dependent variable of this research which is the Employee Performance of Media Café, Kedoya, West Jakarta with an influence level of $19.6 \%$. This shows that the greater the motivation of Media Café employees who altogether consist of the need for achievement, the need for affiliation, and the need for power are met, the greater the performance of the Media Café employees.

Due to the fact that Media Café employees are mostly composed of employees aged 21-30 years who are actively pursuing achievements and power in their careers, researchers suggest:

1. Pay attention to the factors of employee motivation for employee achievement and needs for power. For employee achievement needs, management is advised to provide employees with tasks or jobs that are challenging so they can stimulate new creative ideas from employees. Give feedback from employees so that employees feel valued in their achievements and can continue to improve their performance. For employees' needs for power, management is advised to give employees positions in accordance with their duties and responsibilities and provide clear career paths to their employees in order to motivate their employees to improve their performance so they are able to compete with competitors in the same industry.

2. Carry out further research to determine other factors that can be more influential to the performance of Media Café employees because even though employee motivation factors (the need for achievement and need for power) contribute positively and significantly to employee performance, the effect is only $19.6 \%$, while $80.4 \%$ are factors outside of this study. 


\section{REFERENCES}

Hamid N. 2012. Pengaruh Kepemimpinan, Motivasi dan, Stres Kerja terhadap Kinerja Karyawan pada Bank Syariah Mandiri Kantor Cabang Makasar. Jurnal Analisis, 1 (1). Through http://pasca.unhas.ac.id/jurnal/\#1131 [1/25/2016].

Larasati S, Gilang A. 2014. Pengaruh Motivasi Kerja terhadap Kinerja Karyawan Wilayah Telkom Jabar Barat Utara (Witel Bekasi). Jurnal Manajemen dan Organisasi, Vol. V (3): 200-213

Mangkunegara AAAP. 2007. Manajemen Sumber Daya Manusia Perusabaan (7th Print). Bandung: Rosda.

Murti H, Srimulyani VA. 2013. Pengaruh Motivasi terhadap Kinerja Pegawai dengan Variabel Pemediasi Kepuasan Kerja pada PDAM Kota Madiun. Jurnal Riset Manajemen dan Akuntansi, 1 (1): 10-17.

PT Indocater, Data Unit Manager. 2015. Data Kepuasan Pelanggan Media Café Triwulan III dan IV. Jakarta: Unit Manager Media Café.

2016. Jumlah Karyawan dan Struktur Organisasi Media Café 2016. Jakarta: Unit Manager Media Café.

Ranga, A., \& Kamboj, R. (2018). A study on the Relationship Between Employee Satisfaction and Employees' Performance. TRJ Tourism Research Journal, 2(2), 94 - 104. doi:10.30647/trj.v2i2.43

Salleh F, Dzulkifli Z, Yakoob NHM. 2011. The Effect of Motivation on Job Performance of State Government Employees in Malaysia. International Journal of Humanities and Social Science, 1 (4): 147-154.

Sedarmayanti, Hidayat S. 2011. Metodologi Penelitian (2nd Print). Bandung: Mandar Maju.

Sugiarto. 2015. Metode Statistika Bisnis (1 1 st Print). Tangerang: Matana Publishing.

Sugiarto, Hendratono T, Sudibyo D, 2015. Metodologi Penelitian Hospitaliti dan Pariwisata. Tangerang: Matana Publishing.

Sugiyono. 2011. Metode Penelitian Kuantitatif, Kualitatif, dan ReD. Bandung: Alfabeta.

Suparyadi H. 2015. Manajemen Sumber Daya Manusia Menciptakan Keungoulan Bersaing Berbasis Kompetensi SDM. Yogyakarta: ANDI.

Susan WM, RW Gakure, EK Kiraithe, AG Waititu. 2012. Influence of Motivation on Performance in the Public Security Sector with a Focus to the Police Force in Nairobi, Kenya. International Journal of Business and Social Science, 3 (23): 195-204.

Suwardi, Utomo J. 2011. Pengaruh Motivasi Kerja, Kepuasan Kerja dan Komitmen Organisasional terhadap Kinerja Pegawai (Studi pada Pegawai Setda Kabupaten Pati). Analisis Manajemen, 5 (1): 75-86

Tehubijuluw FK, Sugiarto. 2014. Metodologi Penelitian Cara Mudah Membuat Makalah, Skripsi, Tesis dan Disertasi (1 ${ }^{\text {st }}$ Print). Tangerang: PT Matana Bina Utama. 
Analysis of The Effect of Work Motivation on Performance of Employees in Media Café, Kedoya West Jakarta

Umar H. 2008. Metode Penelitian untuk Skripsi dan Tesis Bisnis (2 ${ }^{\text {nd }}$ Edition). Jakarta: Rajawali Pers.

Wirawan. 2009. Evaluasi Kinerja Sumber Daya Manusia. Jakarta. Salemba Empat. 